\title{
The Akt Pathway Inhibitor Degeulin Prevents Staphylococcal Enterotoxin B Induced Splenocyte Proliferation and Inflammation
}

\author{
Sarah Joanne Christine Whitfield ${ }^{1 *}$, Jane Elizabeth Risdall ${ }^{1,2}$, Gareth Griffiths ${ }^{1}$, \\ Ethel Diane Williamson', Alun James Carter ${ }^{1,3}$ \\ ${ }^{1}$ Department of Biomedical Sciences, Defence Science and Technology Laboratory, Porton Down, Wiltshire, UK \\ ${ }^{2}$ Department of Anaesthesia, University of Cambridge, Cambridge, UK \\ ${ }^{3}$ Department of Medicine, Washington University, St. Louis, Missouri, USA \\ Email: *sjwhitfield@dstl.gov.uk
}

How to cite this paper: Whitfield, S.J.C., Risdall, J.E., Griffiths, G., Williamson, E.D. and Carter, A.J. (2017) The Akt Pathway Inhibitor Degeulin Prevents Staphylococcal Enterotoxin B Induced Splenocyte Proliferation and Inflammation. Advances in Bioscience and Biotechnology, 8, 1-12. http://dx.doi.org/10.4236/abb.2017.81001

Received: December 16, 2016

Accepted: January 7, 2017

Published: January 10, 2017

Copyright $\odot 2017$ by authors and Scientific Research Publishing Inc. This work is licensed under the Creative Commons Attribution-NonCommercial International License (CC BY-NC 4.0).

http://creativecommons.org/licenses/by-nc/4.0/

\begin{abstract}
Staphylococcal Enterotoxin B (SEB) is considered a potential biological weapon. It is toxic by both inhalation and ingestion. Effects of ingestion include fever, vomiting and diarrhoea, while inhalation may additionally result in chest pain, dyspnoea, pulmonary oedema and respiratory failure. Severe exposure may be fatal and treatment relies on symptomatic support. At a cellular level, SEB up-regulates T-cell proliferation leading to a pathological inflammatory response. Deguelin, a rotenoid isolated from the African plant Mundulea sericea (Leguminosae), has been shown to reduce cellular proliferation by inhibiting the phosphoinositide 3-kinase/Akt (PI3K/Akt) signalling pathway. Using isolated murine splenocytes, we have demonstrated that treatment with deguelin reduces SEB inducing $\mathrm{T}$ cell proliferation by $60 \%$. Deguelin treatment also decreased IL-2 and CCL2 secretion by splenocytes exposed to SEB. We demonstrate that targeting cellular proliferation can significantly reduce inflammation after SEB exposure and suggest that antiproliferatives may have a role as potential generic medical counter measures if superantigens are used as biological weapons.
\end{abstract}

\section{Keywords}

Staphylococcal Enterotoxin B, Deguelin, Therapy, Inflammation, Biological Weapon

\section{Introduction}

Staphylococcal enterotoxin B (SEB), an enterotoxin produced by the bacterium Staphylococcu saureus, is classed as a bacterial superantigen (BSAg) [1] [2]. It is 
most commonly associated with food poisoning, but can also cause widespread systemic damage and toxic shock syndrome [3] [4] [5] [6] [7]. SEB is stable to aerosolisation and is toxic via the inhalation of even small amounts. In this form, it causes severe lung pathology, shock and death in man [8] [9]. For this reason, it is considered a potential biological weapon [10] [11]. Clinical signs of intoxication are to some extent dependent on the route of exposure with onset starting 1 to 6 hours after exposure [12]. Signs of inhalational intoxication include fever, respiratory problems, gastrointestinal (GI) symptoms, toxic or septic shock and death [13].

Staphylococcal enterotoxins are extremely potent activators of T-cells and they bind directly to the major histocompatibility complex (MHC) class II molecules on antigen presenting cells (APCs) and to variable $\beta$ chains on T-cell antigen receptors [14] [15] [16]. Under normal conditions, specific proliferation, co-stimulatory recognition and verification signals are required for T-cell activation. Under normal conditions, the percentage of T-cells recruited to affect a response to an antigen is small, $<0.01 \%$ of the T-cell population. In the presence of $\mathrm{SEB}$, there is a significant increase in T-cell activation (approximately $20 \%$ of the T-cell population) [17] [18]. The resultant activation of T-cells leads to the induction of a systemic inflammatory response characterised by the production of significant levels of cytokines, often referred to as the "cytokine storm" [19]. The systemic inflammatory response induced by BSAgs results in numerous immune-pathologies characteristics of superantigen intoxication.

The use of superantigens as potential biological weapons presents military forces with significant challenges in terms of medical countermeasures (MedCMs). The two potential approaches for protection against the effects of weaponised BSAgs are the prophylactic administration of a MedCM prior to exposure or post-exposure treatment. Recent research has looked at the development of effective post-exposure treatments, including agent specific medical countermeasures (e.g. anti-toxins) and wider-spectrum therapies (e.g. anti-inflammatory agents) to target the resulting immunopathology [20]-[26]. One of the more successful broad-spectrum superantigen MedCMs is rapamycin, which targets the PI3K/mTOR pathway, specifically inhibiting mTOR complex 1 [27] [28]. Inhibition of the PI3K/mTOR pathway and subsequent reduction in BSAg toxicity indicates that specific intracellular pathways offer potential therapeutic targets. One potential intracellular target, up-stream of the mTOR complex 1, is Protein Kinase B (Akt). Akt, like mTOR, is involved in the regulation of cellular growth, differentiation, apoptosis and pro-inflammatory signalling [29] [30]. However, modulation of Akt may have greater utility in reducing BSAg pathology, since it has wider involvement in the intracellular signalling processes [31].

Deguelin, a rotenoid from the African plant Mundulea sericea (Leguminosae), has been shown to have anti-carcinogenic properties, including the inhibition of cellular proliferation and induction of apoptosis [32]. These potent effects have been attributed to its inhibitory effect on PI3K/Akt signalling [33]. This study investigates the in vitro efficacy of deguelin, as an inhibitor of the Akt pathway, 
in reducing splenocyte proliferation and the subsequent pro-inflammatory cytokine production.

\section{Materials and Methods}

\subsection{Toxin \& Therapeutics}

SEB toxin was obtained from the Health Protection Agency, Porton Down, Wiltshire, UK and used at a concentration of $0.5 \mu \mathrm{g} / \mathrm{ml}$. Deguelin was purchased from Tocris, UK, and used at concentrations up to $160 \mathrm{nmol} / \mathrm{l}$. Con A and LPS were purchased from Sigma Aldrich and used at concentrations of $3.13 \mu \mathrm{g} / \mathrm{ml}$ and $5 \mu \mathrm{g} / \mathrm{ml}$ respectively. Deguelin was initially dissolved in 10\% DMSO. All remaining reagents and DMOS diluted deguelin were prepared in phosphate buffered saline (Gibco, UK). Working solutions were made on the day of the study carried out using sterile RPMI-1640 media containing 15\% (v/v) fetal calf serum (Sigma-Aldrich, Poole, Dorset, UK), 1\% (v/v) Penicillin/Streptomycin solution and 1\% (v/v) L-Glutamine (Sigma-Aldrich, Poole, Dorset, UK).

\subsection{Splenocyte Preparation}

Fifteen 42 - 49 days old male Balb/C mice (Charles River Laboratories Ltd., Margate, Kent, UK) were killed by cervical dislocation and their spleens aseptically removed. The splenic tissue was then passed through a $10 \mu \mathrm{m}$ cell strainer and the recovered splenocytes re-suspended in supplemented RPMI-1640 medium. Cell suspension was centrifuged for 10 minutes at $350 \mathrm{~g}$ and the supernatant discarded. Red blood cells in the tissue pellet were lysed in $3 \mathrm{ml}$ of red blood cell lysing buffer (Sigma, Dorset UK) for 1 minute. Sterile supplemented RPMI1640 medium was added to give a final volume of $30 \mathrm{ml}$ and the resulting cell suspension centrifuged as above. The supernatant was again discarded. Four milliliters of sterile supplemented RPMI-1640 medium was added, the tissue pellet resuspended and the cell count quantified using a Neubauerhaemocytometer. The volume of the cell suspension was adjusted with supplemented RPMI-1640 medium to give a final cell count of $1.0 \times 10^{6}$ cells $/ \mathrm{ml}$.

\subsection{Cell Cytotoxicity Assay}

A baseline cytotoxicity assay was conducted to establish the relative toxicities of SEB and deguelin, individually and in combination, on splenocytes cultured for 48 hours. Splenocytes were seeded into 96-well flat-bottomed cell culture plates (B. E. Thompson Supplies, Andover, UK) at a cell density of $5 \times 10^{4}$ cells per well and incubated under the following conditions (Table 1).

Table 1 . Slenocyte treatment summary for cytoxicty assay and cytokine analysis.

\begin{tabular}{rcccc}
\hline \multirow{2}{*}{$\begin{array}{c}\text { Splenocyte } \\
\text { treatment }\end{array}$} & \multicolumn{4}{c}{ Treatment group } \\
\cline { 2 - 5 } & Cells & Deguelin + SEB & Degueli $^{\mathrm{n}}$ & SEB \\
\hline Treatment & PBS & $\begin{array}{c}\text { Deg } 160 \mathrm{~nm} / 1+ \\
\text { SEB } 0.5 \mu \mathrm{g} / \mathrm{ml}\end{array}$ & Deg $160 \mathrm{~nm} / 1$ & SEB $0.5 \mu \mathrm{g} / \mathrm{ml}$ \\
\hline
\end{tabular}

a. Deguelin treatment for cytotoxicity assay only. 
After 48 hours, cell death was determined using a Promega Multi-Fluor LDH cytotoxicity assay (Promega, USA), in accordance with the manufacturer's instructions. Dead cell numbers were determined by fluorescence at $485 \mathrm{~nm}$ excitation and $535 \mathrm{~nm}$ emission 3 hours after the addition of the Multi-Fluor reagent. Results were expressed as mean fluorescent intensity (MFI) for each group.

\subsection{SEB-Induced Cell Proliferation (MTT Assay)}

SEB characteristically causes a dose dependent proliferation of T-lymphocytes. The ability of deguelin to inhibit this proliferative effect was measured using a modified cell proliferation technique. Splenocytes were seeded into 96-well flat-bottomed cell culture plates at a cell density of $5 \times 10^{4}$ cells per well. They were then treated with PBS (negative control), SEB (positive control) or SEB and deguelin together. A twofold dilution series of deguelin was used to determine a dose response curve $(160 \mathrm{nmol} / \mathrm{l}$ to $5 \mathrm{nmol} / \mathrm{l})$. After 48 hours incubation, cell proliferation was measured using an MTT assay (Promega, USA). In brief $10 \mu \mathrm{l}$ of the MTT reagent was added to each plate and these were incubated at $37^{\circ} \mathrm{C}$ for a further 4 hours. One hundred microliters of detergent reagent was then added and the plates incubated for a further 3 hours. Cell proliferation was then determined by measuring the absorbance at $570 \mathrm{~nm}$. For each experimental run, the proliferation response of deguelin treated cells was normalised to the negative control (PBS) and the positive control (SEB) at $0 \%$ and $100 \%$ respectively. Analysis was performed on the optical density values and the positive control (SEB) compared with splenocytes treated with SEB and deguelin together. Splenocytes were also separately incubated with Con A as a positive proliferation control and a pro-inflammatory endotoxin control (LPS).

\subsection{ELISA for Cytokines IL-1 $\beta$, IL-2 and MIP-1 Determination}

Quantitative ELISAs (Quantikine) were performed using the cell culture supernatants to determine the effect of deguelin treatment on the production of interleukin-1 $\beta$ (IL-1 $\beta$ ), interleukin-2 (IL-2) and CCL2 by the isolated splenocytes following SEB exposure. Cell culture supernantant were prepared by centrifugation of cultures at $1000 \mathrm{~g}$ for $10 \mathrm{mins}$ at room temperature. Measurement of cytokines by ELISA was performed according to manufacturer's instructions. Splenocytes were also stimulated with the positive proliferation control (Con A) for IL-2 and a pro-inflammatory endotoxin control (LPS) for IL- $1 \beta$ and CCL2. IL- $1 \beta$, IL-2 and CCL2 levels expressed by splenocytes were analysed by comparing SEB-exposed, deguelin treated responses to negative control (PBS) and positive control (SEB) concentrations of cytokines

\subsection{Statistical Analysis}

Statistical analysis was performed using GraphPad Prism 6. Normality of values was determined using a Kolmogorov-Smirnov normality test and appropriate analysis was performed. For the proliferation and cytotoxicity assays, A570 and MFI values of the deguelin treated cells were compared to the SEB (positive con- 
trol) or PBS (negative control) respectively. Matched analysis was performed using a Repeated Measure ANOVA with a Dunnett's post-test. For cytokine analysis, treated cells were compared to PBS (negative control) and SEB, Con A and LPS (positive controls) respectively. For normally distributed data (IL-1 $\beta$ and CCL2) a student T-test was used to determine significance. For non-parametric data (IL-2) a Mann-Whitney test was used to determine statistical significance.

\section{Results}

\subsection{Cell Proliferation Assay}

A reduction of SEB-induced proliferation was observed in cells treated with deguelin, which reached statistical significance at a deguelin concentration of 160 $\mathrm{nmol} / \mathrm{l}(\mathrm{p}<0.01)$ (Figure 1).

\subsection{Cell Cytotoxic Assay}

Treatment of splenocytes with SEB, deguelin or a combination with SEB did not appear to cause any overt cytotoxicity. The MFI measured by the Promega Multi-Fluor cytotoxicity assays after 48 hours is shown in Figure 2. Data are presented as the mean and $95 \%$ CI. No significant differences were observed between untreated splenocytes and the treatment groups $(\mathrm{p}=0.0970$ and $\mathrm{p}=$ 0.3739 , respectively).

\subsection{Cytokine Analysis}

SEB-exposed positive controls secreted $1216 \pm 628 \mathrm{pg} / \mathrm{ml}$ (mean $\pm 95 \% \mathrm{CI}) \mathrm{IL}-2$, significantly higher than untreated splenocytes which produced $146 \pm 101 \mathrm{pg} / \mathrm{ml}$ (mean $\pm 95 \% \mathrm{CI}, \mathrm{p}=0.0017$ ) (Figure 3(a)). The treatment of splenocytes with

Cellular proliferation of SEB treated spleens

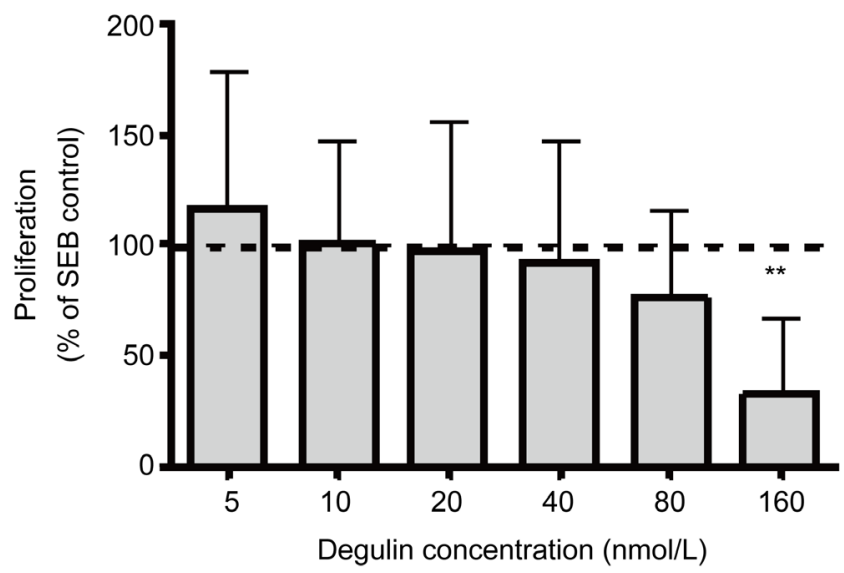

Figure 1. Concentration dependent inhibition of normalised murine splenocyte proliferation by deguelin. Repeated measures ANOVA showed that the effect of treatment was significant differences were observed between treatments $(\mathrm{p}=$ 0.0011). Pos hoc analysis using Dunnett's multiple comparison test are indicated as $^{* *}=\mathrm{p}<0.01$. Mean and $95 \% \mathrm{CI}(\mathrm{n}=5)$. 
Cytotoxicity assay

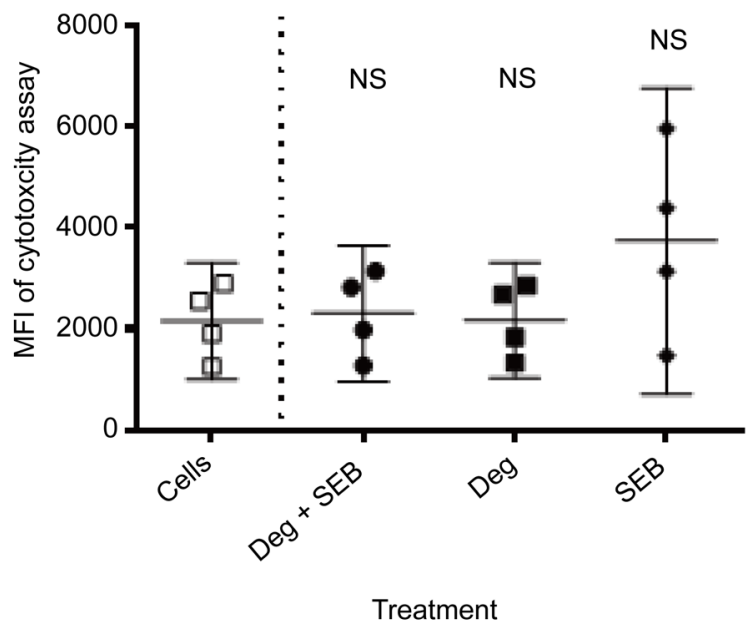

Figure 2. Cytotoxicity measured by MFI. No significant difference was observed in toxicity between control cells and treatments ( $\mathrm{ns}=\mathrm{p}<0.05)$. Bars represent mean MFI and $95 \%$ CI $(n=4)$.

deguelin in the presence of SEB resulted in a significant inhibition of IL-2 production compared to SEB treated control splenocytes $(239 \pm 159 \mathrm{pg} / \mathrm{ml} \mathrm{p}=$ 0.0079). Stimulation of splenocytes with Con A as a control resulted in production of IL-2 (4282 pg/ml) (data not shown).

A significant reduction in CCL2 secretion was observed between SEB treated cells and deguelin treated cells ornegative control cells $(\mathrm{p}=0.0159$ and $\mathrm{p}=$ 0.0317 respectively) (Figure 3(b)). The levels of CCL2 secreted by splenocytes in the deguelin treated group, SEB positive control group and unstimulated negative control group was $66 \pm 89 \mathrm{pg} / \mathrm{ml}$ (mean $\pm 95 \% \mathrm{CI}$ ), $679 \pm 810 \mathrm{pg} / \mathrm{ml}$ (mean $\pm 95 \% \mathrm{CI}$ ) and $73 \pm 150 \mathrm{pg} / \mathrm{ml}$ (mean $\pm 95 \% \mathrm{CI}$ ) (Figure $3(\mathrm{~b})$ ).

The levels of IL- $1 \beta$ production in deguelin treated cells and negative control cells were not significantly different from the levels of cytokines produced by SEB control cells $(\mathrm{p}=0.1392$ and $\mathrm{p}=0.3898$ respectively) (Figures $3(\mathrm{c})$ ). Whilst SEB did not significantly increase IL- $1 \beta$ in splenocytes, there was a trend in reduction of IL- $1 \beta$ between the deguelin treated splenocytes and unstimulated cells as compared to the SEB treated cells $(\mathrm{p}=0.1392$ and $\mathrm{p}=0.3898)$ Figures $3(\mathrm{c})$. Levels of IL- $1 \beta$ and CCL2 production were greatest when splenocytes were stimulated with LPS as a control (109 pg/ml and $2392 \mathrm{pg} / \mathrm{ml}$ respectively) (data not shown).

\section{Discussion}

The aim of this study was to determine the efficacy of deguelin in preventing cellular proliferation and pro-inflammatory cytokine release following SEB exposure in vitro.

There was no apparent cytotoxicity of deguelin in our in vitro system, as evidenced by the result of the cytotoxicity assay. Deguelin treatment of SEB-exposed splenocytes significantly reduced the production of IL-2, a cytokine 


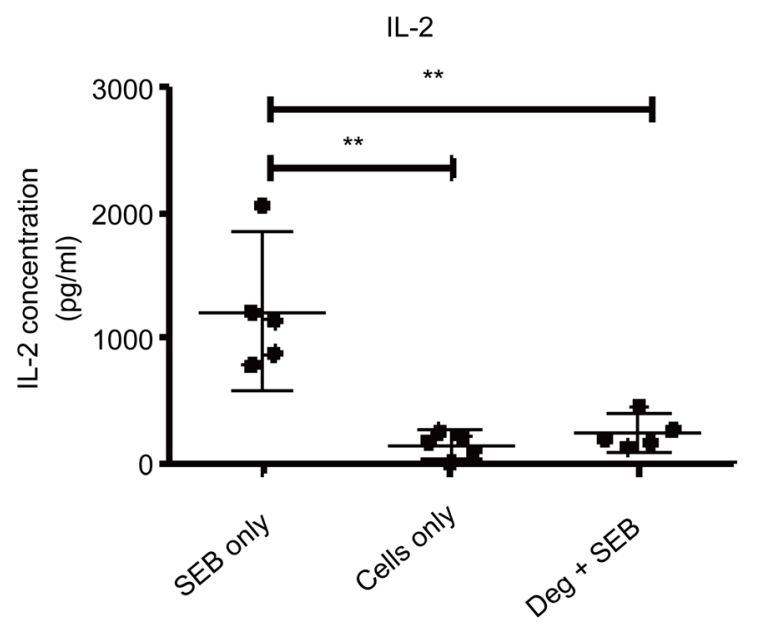

(a)

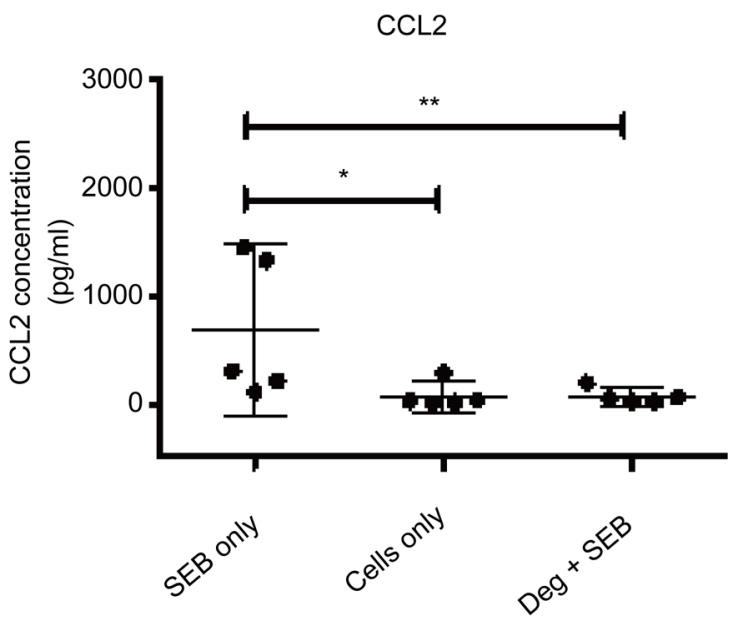

(b)

IL-1 $\beta$

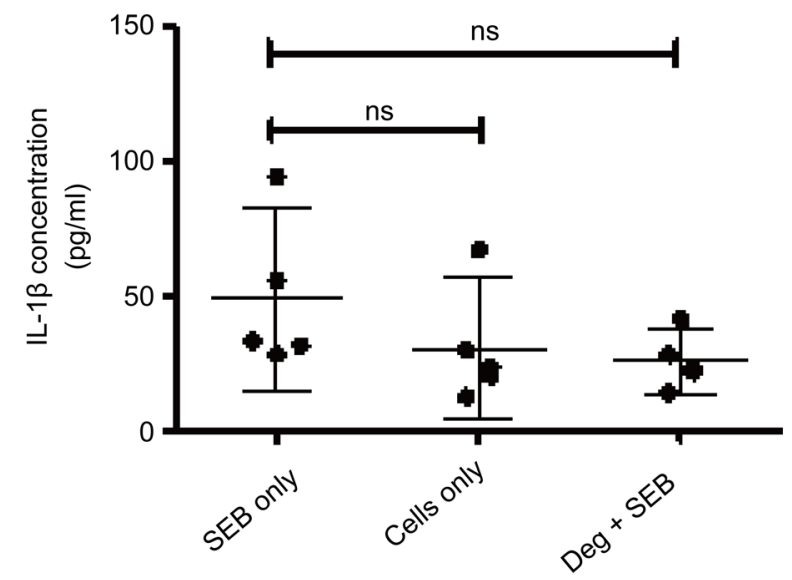

(c)

Figure 3. Murine splenocyte production of IL-2, CCL2 and IL1 $\beta$ following SEB exposure. Isolated splenocytes were treated with PBS (negative control), SEB (positive control) or with SEB and deguelin together. For each experiment, the production of (a) IL-2, (b) CCL2 and (c) IL-1 $\beta$ was measured for the negative control (PBS only), the positive control (SEB only), combined SEB and deguelin treatment (Deg + SEB), a positive proliferation control (Con A) or an endotoxin inflammatory positive control (LPS) (data not shown). Significant differences are indicated $n s=p>0.05$; ${ }^{*}=\mathrm{p}<0.05 ;{ }^{* *}=\mathrm{p}<0.01$. Bars represent mean and 95\% CI $(\mathrm{n}=5)$.

essential for T-cell proliferation and activation, and the chemokine CCL2, which initiates the migration of monocytes into systemic tissues [34] [35] [36]. Whilst deguelin did not significantly reduce IL- $1 \beta$, a pro-inflammatory cytokine involved in the acute phase response, a trend in cytokine section was observed. The biological mechanism of SEB toxicity is well defined. SEB interacts with the T-cell/APC immune synapse (MCH class II molecules on APCs, the $\beta$-chain on T-cell receptors) by passing the need for T-cells to recognize antigen [37] [38]. Secondary signals are required for T-cell survival and proliferation, and production of pro-inflammatory cytokines resulting in superantigen toxicity [39] [40] [41] [42].

Targeting T-cell proliferation would seem a reasonable approach to counteract the effects of SEB exposure. However, the prevention of cellular prolifera- 
tion and differentiation of T-cells has largely been ignored. PI3K/mTOR intracellular signaling regulates proliferation. This pathway is dependent upon chemokine, IFN- $\gamma$ and IL-2 receptor cell signaling for proliferation and T-cell activation [43] [44] [45]. Rapamycin is one of the few therapeutics that have been shown to be effective at preventing superantigen toxicity in vivo [23].

The mechanism by which deguelin reduces proliferation has been extensively studied and is identified as a potential therapeutic due to its effect on Akt. Deguelin binds directly to Hsp90 inhibiting its biological activity [46]. Hsp90 stabilises signaling molecules include Akt and PI3K, inhibiting the PI3K/Akt pathway [47]. This pathway is involved in the regulation of many cellular processes including cellular growth, differentiation, cell survival and apoptosis [47]. We hypothesised that by blocking the intracellular signaling associated with this pathway, it should be possible to prevent T-cell proliferation and this would reduce the inflammatory response. This study demonstrates both a reduction in cellular proliferation and in inflammatory cytokine production following deguelin treatment of splenocytes exposed to SEB in vitro.

PI3K/Akt signaling is necessary for numerous pro-inflammatory processes including cytokine receptor signaling, the induction of pro-inflammatory cytokine production, increased expression of adhesion molecules (intergrins and selectins), superoxide production, neutrophil degranulation and the expression of IFN-inducible proteins [29]. The observed reduction in pro-inflammatory cytokines following deguelin treatment may be due to inhibition of this signaling pathway. PI3K/Akt/mTOR intracellular signaling also modulates inflammatory receptor signals, including the immune synapse complex, interleukin 1 receptor, Toll-like receptors, TNF receptor, chemokine receptors and interferon receptor, all of which have been implicated in superantigen toxicity [48] [49]. The resultant pro-inflammatory cellular responses lead to increased production of cytokines and chemokines including IL- $1 \beta$, TNF- $\alpha$, IL-6, IL-12, CCL2, CCL5 and IFN- $\gamma$ [50] [51]. Furthermore, deguelin has been previously shown to inhibit IкB $\alpha$ kinase activation and reduce nucleoporin Nup88 expression, both of which suppress of NF- $\kappa B$ dependent gene expression [52]. NF- $\kappa B$ is considered a key transcription factor for the production and regulation of the pro-inflammatory response. Deguelin suppression of NF- $\mathrm{kB}$ transcription of pro-inflammatory genes may also explain reduced pro-inflammatory cytokine production following SEB exposure.

From our studies, it would appear that deguelin reduced SEB-induced cellular proliferation and pro-inflammatory cytokine production. Although showing promising anti-cancer activity in the laboratory, deguelin has not been developed for clinical use. Several other Akt inhibitors, such as VQD-002, perifosine and miltefosine, have been developed for use in the treatment of cancer and protozoal infections [53] [54]. These drugs may represent potential treatments for SEB intoxication.

Additional cellular targets influencing the PI3K/Akt pathway include inhibitors of IL-2 receptor signaling, such as basiliximab, daclizumab and inhibitors of 
CD28 signaling, such as abatacept [55]. Further research will be required to demonstrate the efficacy of these agents in preventing superantigen toxicity in vivo. However, targeting PI3K/Aktsignaling and/or T-cell proliferation in BSAg intoxication may prevent the inflammatory response progressing with positive effects on morbidity and mortality.

Here we have demonstrated for the first time, that a PI3K/Akt pathway inhibitor is effective in preventing superantigen-induced cellular proliferation. This in vitro system also has the potential to offer rapid screening of other putative therapeutic agents for use in SEB intoxication.

\section{Acknowledgements}

All the authors thank Chris Taylor (DSTL) and comments during this research.

\section{References}

[1] Pinchuk, I.V., Beswick, E.J. and Reyes, V.E. (2010) Staphylococcal Enterotoxins. Toxins, 2, 2177-2197. https://doi.org/10.3390/toxins2082177

[2] Krakauer, T. and Stiles, B.G. (2003) Staphylococcal Enterotoxins, Toxic Shock Syndrome Toxin-1, and Streptococcal Pyrogenic Exotoxins: Some Basic Biology of Bacterial Superantigens. Recent Research Developments in Infection and Immunity, 1, 1-27.

[3] Nema, V., Agrawal, R., Kamboj, D.V., Goel, A.K. and Singh, L. (2007) Isolation and Characterization of Heat Resistant Enterotoxigenic Staphylococcus aureus from a Food Poisoning Outbreak in Indian Subcontinent. International Journal of Food Microbiology, 117, 29-35. https://doi.org/10.1016/j.ijfoodmicro.2007.01.015

[4] Argudín, M.Á., Mendoza, M.C. and Rodicio, M.R. (2010) Food Poisoning and Staphylococcus aureus Enterotoxins. Toxins, 2, 1751-1773. https://doi.org/10.3390/toxins2071751

[5] James, S.P. (1993) Potential Role of Superantigens in Gastrointestinal Disease. Gastroenterology, 105, 1569-1571. https://doi.org/10.1016/0016-5085(93)90169-D

[6] Schlievert, P.M. (1993) Role of Superantigens in Human Disease. The Journal of Infectious Diseases, 167, 997-1002. https://doi.org/10.1093/infdis/167.5.997

[7] Kumar, S., Ménoret, A., Ngoi, S.-M. and Vella, A.T. (2010) The Systemic and Pulmonary Immune Response to Staphylococcal Enterotoxins. Toxins, 2, 1898-1912. https://doi.org/10.3390/toxins2071898

[8] Burnett, J.C., Henchal, E.A., Schmaljohn, A.L. and Bavari, S. (2005) The Evolving Field of Biodefence: Therapeutic Developments and Diagnostics. Nature Reviews Drug Discovery, 4, 281-296. https://doi.org/10.1038/nrd1694

[9] Roy, C.J., Warfield, K.L., Welcher, B.C., Gonzales, R.F., Larsen, T., Hanson, J., et al. (2005) Human Leukocyte Antigen-DQ8 Transgenic Mice: A Model to Examine the Toxicity of Aerosolized Staphylococcal Enterotoxin B. Infection and Immunity, 73, 2452-2460. https://doi.org/10.1128/iai.73.4.2452-2460.2005

[10] Madsen, J.M. (2001) Toxins as Weapons of Mass Destruction. A Comparison and Contrast with Biological-Warfare and Chemical-Warfare Agents. Clinics in Laboratory. Medicine, 21, 593-605.

[11] Rusnak, J.M., Kortepeter, M., Ulrich, R., Poli, M. and Boudreau, E. (2004) Laboratory Exposures to Staphylococcal Enterotoxin B. Emerging Infectious Diseases, 10, 1544-1549. https://doi.org/10.3201/eid1009.040250 
[12] Paddle, B.M. (2003) Therapy and Prophylaxis of Inhaled Biological Toxins. Journal of Applied Toxicology, 23, 139-179. https://doi.org/10.1002/jat.903

[13] Stiles, B.G., et al. (1993) Toxicity of Staphylococcal Enterotoxins Potentiated by Lipopolysaccharide: Major Histocompatibility Complex Class II Molecule. Infection and Immunity, 61, 5333-5338.

[14] Krakauer, T. (2010) Therapeutic Down-Modulators of Staphylococcal Superantigen-Induced Inflammation and Toxic Shock. Toxins, 8, 1963-1983. https://doi.org/10.3390/toxins2081963

[15] Karazaum, H., et al. (2012) Synthetic Human Monoclonal Antibodies toward Staphylococcal Enterotoxin B (SEB) Protective against Toxic Shock Syndrome. Journal of Biological Chemistry, 287, 25203-25215. https://doi.org/10.1074/jbc.M112.364075

[16] Sundberg, E.J., Deng, L. and Mariuzza, R.A. (2007) TCR Recognition or Peptide/MHC Class II Complexes and Superantigens. Seminars in Immunology, 19, 262 271. https://doi.org/10.1016/j.smim.2007.04.006

[17] Huvenne, W., et al. (2011) Exacerbation of Cigarette Smoke-Induced Pulmonary Inflammation by Staphylococcus aureus Enterotoxin B in Mice. Respiratory Research, 12, 69. https://doi.org/10.1186/1465-9921-12-69

[18] Krakauer, T. (2013) Update on Staphylococcal Superantigen-Induced Signalling Pathways and Therapeutic Interventions. Toxins, 9, 1629-1654. https://doi.org/10.3390/toxins5091629

[19] Tilahun, M.E., et al. (2010) Potent Neutralization of SEB by Synergistic Action of Chimeric Antibodies. Infection and Immunity, 78, 2801-2811. https://doi.org/10.1128/IAI.01121-09

[20] Krakauer, T. (1995) Differential Inhibitory Effects of Interleukin-10, Interleukin-4, and Dexamethasone on Staphylococcal Enterotoxin-Induced Cytokine Production and T Cell Activation. Journal of Leukocyte Biology, 57, 450-454.

[21] LeClaire, R.D., Kell, W., Bavari, S., Smith, T.J. and Hunt, R.E. (1996) Protective Effects of Niacinamide in Staphylococcal Enterotoxin B Induced Toxicity. Toxicology, 107, 69-81. https://doi.org/10.1016/0300-483X(95)03202-Q

[22] Krakauer, T., Buckley, M., Issaq, H.J. and Fox, S.D. (2010) Rapamycin Protects Mice from Staphylococcal Enterotoxin B-Induced Toxic Shock and Blocks Cytokine Release in Vitro and in Vivo. Antimicrobial Agents and Chemotherapy, 54, 11251131. https://doi.org/10.1128/AAC.01015-09

[23] Krakauer, T. (2007) Superantigen-Indiced Cytokine Release from Whole Blood Cell Culture as a Functional Measure of Drug Efficacy after Oral Dosing in Non-Human Promates. Research in Veterinary Science, 83, 182-187. https://doi.org/10.1016/j.rvsc.2006.12.004

[24] Solanki, L.S., Srivastava, N. and Singh, S. (2008) Superantigens: A Brief Review with Special Emphasis on Dermatologic Diseases. Dermatology Online Journal, 14, 3.

[25] Wang, S., Li, Y., Xiong, H. and Cao, J. (2008) A Broad-Spectrum Inhibitory Peptide against Staphylococcal Enterotoxin Superantigen SEA, SEB and SEC. Immunology Letters, 121, 167-172. https://doi.org/10.1016/j.imlet.2008.10.007

[26] Krakauer, T., et al. (2010) Rapamycin Protects Mice from Staphylococcal Enterotoxin B-Induced Toxic Shock and Blocks Cytokine Release in Vitro and in Vivo. Antimicrobial Agents and Chemotherapy, 54, 1125-1131. https://doi.org/10.1128/AAC.01015-09

[27] Krakauer, T. and Buckley, B. (2012) Intranasal Rapamycin Rescues Mice from Staphylococcal Enterotoxin B-Induced Shock. Toxins, 4, 718-728. 
https://doi.org/10.3390/toxins4090718

[28] Krakauer, T. (2012) P13K/Akt/mTOR, a Pathway Less Recognised for Staphylococcal Superantigen-Induced Toxicity. Toxins, 11, 1343-1366.

https://doi.org/10.3390/toxins4111343

[29] Morgensztern, D. and McLeod, H. (2005) P13K/Akt/mTOR Pathway as a Target for Cancer Therapy. Anti-Cancer Drugs, 16, 797-803. https://doi.org/10.1097/01.cad.0000173476.67239.3b

[30] Scholl, P.R., et al. (1992) Role of Protein Tyrosine Phosphorylation in Monokine Induction by the Staphylococcal Superantigen Toxic Shock Syndrome Toxin-1. Journal of Immunology, 148, 2237-2241.

[31] Nair, A.S., et al. (2006) Deguelin, an Akt Inhibitor, Suppresses IкB $\alpha$ Kinase Activation Leading to Suppression of NF-kB-Regulated Gene Expression, Potentiation of Apoptosis, and Inhibition of Cellular Invasion. Journal of Immunology, 177, 56125622. https://doi.org/10.4049/jimmunol.177.8.5612

[32] Kang, H.W., et al. (2012) Deguelin, an Akt Inhibitor, Down-Regulates NF-kB Signaling and Induces Apoptosis in Colon Cancer Cells and Inibitstumour Growth in Mice. Digestive Diseases and Sciences, 57, 2873-2882. https://doi.org/10.1007/s10620-012-2237-x

[33] Khan, A.A., Priya, S. and Saha, B. (2009) IL-2 Regulates SEB Induced Toxic Shock Syndrome in Balb/C Mice. PLoS ONE, 12, e8473. https://doi.org/10.1371/journal.pone.0008473

[34] Geissmann, F., Jung, S. and Littmann, D.R. (2003) Blood Monocytes Consist of Two Principle Subsets with Distinct Migratory Properties. Immunity, 19, 71-82. https://doi.org/10.1016/S1074-7613(03)00174-2

[35] Faulkner, L., Cooper, A., Fantino, C., Altmann, D.M. and Sriskandan, S. (2005) The Mechanism of Superantigen-Mediated Toxic Shock: Not a Simple Th1 Cytokine Storm. Journal of Immunology, 175, 6870-6877. https://doi.org/10.4049/jimmunol.175.10.6870

[36] Fraser, J.D. (2011) Clarifying the Mechanism of Superantigen Toxicity. PLoS ONE, 9, e1001145. https://doi.org/10.1371/journal.pbio.1001145

[37] Fraser, J.D. and Proft, T. (2008) The Bacterial Superantigen and Superantigen-Like Proteins. Immunological Reviews, 225, 226-243. https://doi.org/10.1111/j.1600-065X.2008.00681.x

[38] Kaempfer, R., Arad, G., Levy, R., Hillman, D., Nasie, I. and Rotfogel, Z. (2013) CD28: Direct and Critical Receptor for Superantigen Toxins. Toxins, 9, 1531-1542. https://doi.org/10.3390/toxins5091531

[39] Fraser, J.D., Newton, M.E. and Weiss, A. (1992) CD28 and T Cell Antigen Receptor Signal Transducition Coordinately Regulate Interleukin 2 Gene Expression in Response to Superantigen Stimulation. Journal of Experimental Medicine, 175, 11311134. https://doi.org/10.1084/jem.175.4.1131

[40] Stebbings, R., et al. (2007) Cytokine Storm in the Phase I Trial of Monoclonal Antibody TGN1412: Better Understanding the Causes to Improve Pre-Clinical Testing of Immunotherapeutics. Journal of Immunology, 179, 3325-3331. https://doi.org/10.4049/jimmunol.179.5.3325

[41] Geller-Hong, E., Möllhoff, M., Shiflett, P.R. and Gupta, G. (2004) Design of Chimeric Receptor Mimics with Different TcRV $\beta$ Isoforms: Type-Specific Inhibition of Superantigen Pathogenesis. Journal of Biological Chemistry, 279, 5676-5684. https://doi.org/10.1074/jbc.M309388200

[42] Krakauer, T., Buckley, M. and Fisher, D. (2010) Pro-Inflammatory Mediators of Toxic Shock and Their Correlation to Lethality. Mediators of Inflammation, 2010, 
Article ID: 517594. https://doi.org/10.1155/2010/517594

[43] Stentz, F.B. and Kitabachi, A.E. (2004) Transciptome and Proteome Expression in Activated Human CD4 and CD8 T Lymphocytes. Biochemical and Biophysical Research Communications, 324, 692-696. https://doi.org/10.1016/j.bbrc.2004.09.113

[44] Kim, E.H. and Suresh, M. (2013) Role of P13K/Aktsignalling in Memory CD8 T Cell Differentiation. Frontiers in Immunology, 4, 20. https://doi.org/10.3389/fimmu.2013.00020

[45] Wang, Y., Ma, W. and Zheng, W. (2013) Deguelin, a Novel Anti-Tumorigenic Agent Targeting Apoptosis, Cell Cycle Arrest and Anti-Angiogenesis for Cancer Chemoprevention. Molecular and Clinical Oncology, 1, 215-219.

[46] Fujita, N., Sato, S., Ishida, A. and Tsuruo, T. (2002) Involvement of Hsp90 in Signalling and Stability of 3-Phosphoinositide-Dependant Kinase-1. Journal of Biological Chemistry, 277, 10346-10353. https://doi.org/10.1074/jbc.M106736200

[47] Buxade, M., et al. (2001) Intergrating Signals from T Cell Receptor and Serum by T Cells Enhance Translation of Tumour Necrosis Factor-Alpha. Immunology, 102, 416-425. https://doi.org/10.1046/j.1365-2567.2001.01206.x

[48] Dunn, G.P., Koebel, C.M. and Schreiber, R.D. (2006) Interferons, Immunity and Cancer Immunoediting. Nature Reviews Immunology, 6, 836-848. https://doi.org/10.1038/nri1961

[49] Huzella, L.M., Buckley, M.J., Alves, D.A., Stiles, B.G. and Krakauer, T. (2009) Central roles for IL-2 and MCP-1 Following Intranasal Exposure to SEB: A New Mouse Model. Research in Veterinary Science, 86, 241-247. https://doi.org/10.1016/j.rvsc.2008.07.020

[50] Shin, J., Pan, H. and Zhong, X. (2011) Regulation of Mast Cell Survival and Function by Tuberous Sclerosis Complex 1. Blood, 119, 3306-3314. https://doi.org/10.1182/blood-2011-05-353342

[51] Shu, W., Chen, Y., Wu, Q., Li, R. and Cui, G. (2008) Deguelin Represses both the Expression of Nucleophosmin and Some Nucleoporins: Nup88 and Nup214 in Jurkat Cells. Biological and Pharmaceutical Bulletin, 31, 27-32. https://doi.org/10.1248/bpb.31.27

[52] Zitzmann, K., et al. (2012) Perifosine-Mediated Akt Inhibition in Neuroendocrine Tumour Cells: Role of Specific Akt Isoforms. Endocrine-Related Cancer, 19, 423434. https://doi.org/10.1530/ERC-12-0074

[53] Bhatt, A., et al. (2009) Dual Inhibition of PI3K and mTOR Inhibits Autocrine and Paracrine Proliferative Loops in PI3K/AKt/mTOR-Addicted Lymphomas. Blood, 115, 4455-4463. https://doi.org/10.1182/blood-2009-10-251082

[54] Mukherjee, S. and Mukherjee, U. (2009) A Comprehensive Review of Immunosuppression Used in Liver Transplantation. Journal of Transplantation, 2009, Article ID: 701464. https://doi.org/10.1155/2009/701464

[55] Romo-Tena, J., Martin, D. and Alcocer-Varela, J. (2013) CTLA-4 and Autoimmunity: New Insights in the Dual Regulator of Tolerance. Autoimmunity Reviews, 12, 1171-1176. https://doi.org/10.1016/j.autrev.2013.07.002 
Submit or recommend next manuscript to SCIRP and we will provide best service for you:

Accepting pre-submission inquiries through Email, Facebook, LinkedIn, Twitter, etc. A wide selection of journals (inclusive of 9 subjects, more than 200 journals)

Providing 24-hour high-quality service

User-friendly online submission system

Fair and swift peer-review system

Efficient typesetting and proofreading procedure

Display of the result of downloads and visits, as well as the number of cited articles Maximum dissemination of your research work

Submit your manuscript at: http://papersubmission.scirp.org/

Or contact abb@scirp.org 